FACTA UNIVERSITATIS

Series: Economics and Organization Vol. 18, № 1, 2021, pp. 73 - 87

https://doi.org/10.22190/FUEO201102006J

Original Scientific Paper

\title{
ARE COSTS STICKY? EVIDENCE FROM SERBIA
}

UDC 657.471.1(497.11)

\section{Jovana Jugović}

University of Belgrade, Faculty of Economics, Belgrade, Serbia

\begin{abstract}
This paper is focused on the theory of sticky costs, created out of researches which pointed to the fact that costs do not act symmetrically in the case of equivalent increase and decrease of the activity volume, as it is implied by the traditional cost theory. Deliberate business decisions, the ones made in order to increase company's value, as well as opportunistic decisions aimed at the realization of managers' personal goals are found as some of essential causes of cost stickiness. In order to examine the phenomenon of stickiness in the cost behavior of companies that operate in Serbia, we conducted a research on a sample of 917 medium and large companies from manufacturing sector for the period 2007 - 2016. The analysis of panel data pointed to the presence of stickiness in the behavior of operating costs - it showed that they grow by $0.847 \%$ as revenues grow by $1 \%$, and they fall by $0.718 \%$ due to $1 \%$ drop in revenues. We also found a lagged adjustment to operating costs for changes in operating revenues and partial reversal of stickiness in the period after a revenue decrease.
\end{abstract}

Key words: cost behavior, cost stickiness, adjustments costs, behavioral finance, agency theory

JEL Classification: M41, D24, G40

\section{INTRODUCTION}

Cost behavior is the way costs respond to the changes in cost drivers. Efficient cost management assumes understanding of the cost functions because of cost planning, calculation and control. Cost management is imposed as a complex task, having in mind that different purposes of using information about the costs demand cost categorization to be done in different ways. Managers need to make many decisions based precisely on the information about the costs: whether to introduce a new product in the assortment or eliminate some of the existing ones; produce or buy at the external market; sell or process

Received November 02, 2020 / Revised January 18, 2021 / Accepted January 21, 2021

Corresponding author: Jovana Jugović

University of Belgrade, Faculty of Economics, Kamenička 6, 11000 Belgrade, Serbia

E-mail: jovana.jugovic@ekof.bg.ac.rs

ㄷ 2021 by University of Niš, Serbia | Creative Commons Licence: CC BY-NC-ND 
further and the like. The analysis of cost behavior is supposed to be put in the context of how the resource consumption changes along with the change of activity volume.

This paper is organized as follows. The basic ideas of sticky cost theory are described in section 1 and compared with the traditional one. Section 2 identifies three groups of factors that determine business decisions whose realization causes cost stickiness: adjustment costs, managers' personal benefits and behavioral factors. The results of panel analysis, conducted with the aim to test cost stickiness in operating costs of manufacturing companies in Serbia, are presented in section 3, as well as author's interpretation of the results.

\section{COST BEHAVIOR: TRADITIONAL AND STICKY COST THEORY}

Traditional cost theory classifies costs in two groups, depending on the way costs, in the overall amount, react to the change of activity volume: fixed and variable costs. Unlike fixed, whose total amount does not change in the short term, the total variable costs change not only linearly, but also in proportion to the change in the activity volume. Reaction of variable costs to the change of activity level is symmetrical in both directions, which means that this category reacts uniformly both to the increase and equivalent decrease of the activity volume. Thus, direction and volume of the change of activity are irrelevant for the change of costs. The magnitude of a change in costs will be the same, regardless of whether the activity goes from lower to upper volume or viceversa, as well as whether it is about a relatively small or relatively big change of the activity volume. Besides these two basic groups, there is also the third one - mixed costs which, due to the effects of economies of scale, learning curves and the like, show characteristics of both previous groups. Still, "these extensions continue to assume a mechanistic relation between cost driver quantities and costs, leaving no room for deliberate managerial decisions motivated by various economic constraints, incentives, and biases" (Banker et al., 2018, p. 192-193). Upon categorizing costs to fixed and variable ones it is necessary to bear in mind that this classification is conditioned by a relevant range of activities, and it was done in relation to the time period being observed. Curve of overall costs shows symmetrical behavior of costs. Traditional cost accounting theory, as opposed to economic theory, presents total costs as a linear function of the activity volume, for the relevant range of activities. The reason for this is that the cost curve is almost linear in any relevant range of activities, as shown in Figure 1, so the linearity assumption is used for the purposes of short-term planning, calculation and control of costs.

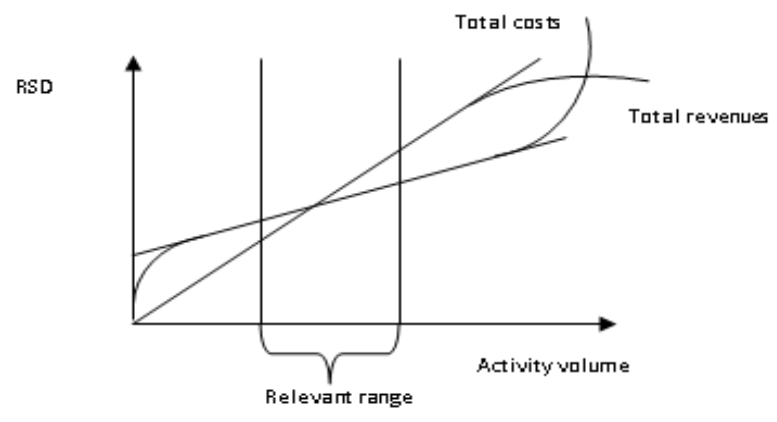

Fig. 1 Cost and revenue function Source: Malinić et al., p. 324 
Some empirical studies, however, showed that costs do not act symmetrically, as traditional theory claims. The results of these studies pointed out the fact that costs react more to the increase than to equivalent decrease of the activity volume. If demand exceeds the available capacity of existing resources, it will lead to the increase of capacity by acquiring additional resources, which is aimed at absorbing greater demand. However, in case unused capacities exist, "some committed resources will not be utilized unless managers make the deliberate decision to remove them" (Anderson et al., 2003, p. 49). Costs will be fixed only if the management does not take any action regarding the reduction of unused capacities. This can be an indicator of active cost management. The first empirical confirmation of this idea comes from the research of Noreen \& Soderstrom (1997). The authors showed that costs adjust more difficultly to the fall than to the increase of the activity volume, pointing to a different pattern of cost behavior as determined by the direction of the change of the activity. Also, Hamerman and Pfann (1996) stressed there is no necessary reason why the marginal cost of increasing activity would be the same as that of an equal-size decrease.

However, this idea gains importance after the publishing of the research of Anderson et al. (2003) which opened 'the black box' about the cost behavior and motivated research in the field. Authors used the sample of 7,629 industrial companies, observing the period of 20 years $(1979-1998)$ and showed that sales, general and administrative costs act asymmetrically. In other words, these costs grow by $0.55 \%$ on average upon the increase of sales by $1 \%$, and on average they decrease by only $0.35 \%$ in case of $1 \%$ fall in sales. This kind of cost behavior is named ,sticky" by the authors. "Costs are sticky if the magnitude of the increase in costs associated with an increase in volume is greater than the magnitude of the decrease in costs associated with an equivalent decrease in volume" (Anderson et al., 2003, 48). So that, according to sticky cost theory, costs are determined both by the change of volume and the direction of activities (Banker \& Byzalov, 2014), unlike traditional cost theory claims, which can be presented:

$$
\Delta \mathrm{C}=f(\Delta \mathrm{q}, \text { direction of change } \mathrm{q}),
$$

where:

$\mathrm{C}$ - amount of overall costs of a certain category, $\mathrm{q}$ - activity volume. ${ }^{2}$

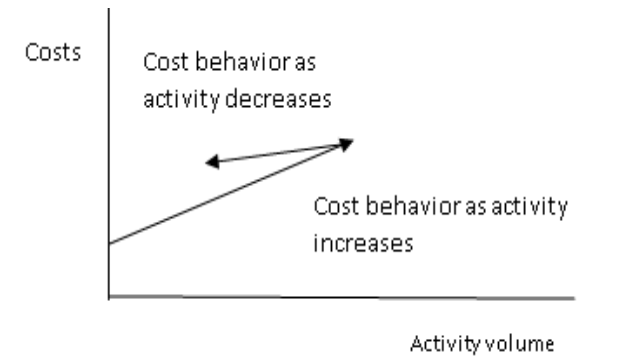

Fig. 2 Sticky costs

Source: Maher, Stickey, Weil (2008), p. 160

\footnotetext{
${ }^{2}$ It would be important to stress that the unlinearity in the behavior of costs is not an equivalent to sticky cost behavior. In case of nonlinear behavior, the same as with linear behavior, marginal costs are determined exclusively by the change of the activity volume, not by the change of direction, while in the case of sticky cost behavior marginal costs were determined both by the change of volume and change of the direction of activity. More to be seen in Banker and Bzyalov (2014).
} 
Anderson et al. (2003) consider deliberate decision making on resource adjustments as the primary cause of stickiness in the cost behavior. Cost stickiness is just one of many ways how managerial decisions may affect cost behavior (Banker et al., 2018). Numerous researches also highlight the importance of the managers' characteristics and behavior for cost stickiness (Kama \& Weiss, 2010; Chen et al. 2012; Dierynck et al. 2012; Qin et al. 2015; Salamah \& Abulezz, 2017).

Taking into account time component, as numerous authors have shown (e.g. Andersen et al. 2003; Dalla Via \& Perego 2014), delayed decision-making and contracting lags cause cost stickiness observed in one period to be reversed in subsequent periods. Changes in revenues may reflect current market conditions and may be an indicator of long-term orientation in terms of demand for the company's products. Therefore, if there is a drop in demand, managers will need some time to gather information on the basis of which they will conclude about the cause of the fall and make decisions about reducing resources. In addition, even after a decision has been made to reduce resources, it often takes some time for that decision to reflect on cost reduction since contractual arrangements take time to be undone. These time lags will result in cost stickiness bearing in mind that companies will maintain unused resources during the period between the reduction in volume and the adjustment decision. The consequence of this will be that the stickiness observed in one period might be reverted in subsequent periods.

\section{Deliberate Decision Making as CaUSE of Cost Stickiness}

Decisions of the business entity may be a factor of cost variability (Malinić et al., 2019, p. 219). "Managers choose resource levels subject to various constraints (e.g., demand conditions, production technology, resource adjustment costs, strength of corporate governance, debt covenants, government regulation), incentives (e.g., performance compensation, earnings targets, ownership type, stakeholder activism), and biases (e.g., overconfidence)" (Banker et al., 2018, p. 195). Managers choose different resource levels for the same activity volume depending on whether it is the upward or downward resource adjustment (Anderson et al, 2003). On that occasion, managers make those decisions whose realization they expect to produce the increase of company's value, as well as the ones which will bring them the fruition of personal benefits, while neglecting the effects that the realization of those decisions could have for the company. We identify three groups of factors that determine business decisions whose realization causes cost stickiness: adjustment costs, managers' personal benefits and behavioral factors.

Companies change their demand for resources more slowly than shocks require (Hamermesh \& Pfann,1996, p. 1264.) Explanation of this phenomenon lies in adjustment cost, concept which was first presented by Lucas (1967). In case of external shocks, caused by the change of demand, it is impossible to adapt resources to changed circumstances regarding the need for them, without following cost adjustments. Dismissal, as well as the employment of additional units of resources, entails certain adjustment costs. These can be explicit costs, expressed in monetary units, such as severance costs, costs of organizing vacancies, costs of training and education of new employees, disposal costs, equipment installation costs. However, implicit costs that are not covered by the accounting information system, such as the decline in employee morale due to dismissals, should not be overlooked. These costs may be reflected in the 
financial statements of some future periods, for example, by increasing costs due to reduced efficiency and productivity.

Cost-benefit analysis is based on the comparison of costs of maintaining unused capacities and adjustment costs. In case of the drop in demand, the release of resources would happen to the point where managers would become indifferent to either releasing or keeping the additional resource unit. In this case keeping resources could be done, not only with the intention to avoid current, but also future cost adjustments, which would occur in case there was a need to acquire additional resource units. Contrary to drop, a more considerable increase of market demand can be absorbed only if necessary resources were acquired so that a larger volume of business activities could be performed, under the assumption of complete exploitation of the existing resources. "Managers' resource commitments depend not only on concurrent sales, but also on (1) prior period resource levels, which affect adjustment costs that have to be incurred in the current period, (2) expected future sales, which affect future adjustment costs, and (3) agency and behavioral factors, which drive a wedge between optimal decisions for the firm and managers' actual choices" (Banker \& Byzalov, 2014, p. 47). Proving cost stickiness of overheads is quite challenging. Novák et al. (2017) showed that the variability of overheads is affected by the two factors - production in $\mathrm{kg}$ and total production in minutes - in the previous reporting period (month). "In contrast, a fixed/variable model of cost behavior asserts that the amount of costs incurred depends on the volume of realized activity in the current period only" (Balakrishnan \& Gruca, 2008, p. 994).

Some resources, such as raw material, are purchased with the expectation that they will be consumed in the production process in a short period of time. Organizations commit, however, to making many other resources available whether or not the resources will be fully used for current and future activities (Cooper \& Kaplan, 1992), such as buildings, machines, equipment. Managers will rather keep a larger volume of the resources, whose adjustment to current circumstances causes high costs, both explicit and implicit, than do what the existing activity level demands. Exploiting such resources creates a curve of conventional fixed costs. Accordingly, fixed and variable costs are two extreme cost categories determined by higher or lower cost adjustments. If cost adjustments are lower, we can expect that the change of costs will follow the change of the activity volume that caused it. Some forms of costs may be classified as variable or fixed costs with huge difficulties, as they behave differently in different situations, such as logistics costs, which is of special interest for cost management (see e.g. Novák et al., 2018). Adjustment costs may vary with institutional and contractual arrangements (Banker \& Byzalov, 2014). This implies consideration of macro environment, characteristics of sector, capital market movements, labor legislation and social security, contractual obligations to suppliers and the like (see e.g. Guenther et al., 2014). Also, as observed by Li \& Zheng (2017), management in financially stronger firms has more resources for investment expenditures in spite of a sales fall that can also cause cost stickiness.

Empirical research on the impact of adjustment costs on the level of cost stickiness has been hampered by difficulties in calculating adjustment costs. Banker et al. (2013) investigated the correlation between employment protection and cost stickiness for companies from OECD member countries. They concluded that stricter regulation, which implies higher adjustment costs, is associated with a higher level of cost stickiness, which is in line with theoretical assumptions.

Upon the analysis of factors that determine managers' decisions it is inevitable that in specific circumstances the decisions will be motivated, not by maximizing the value of 
company, but by maximizing managers' personal benefits. Jensen's agency theory foresees that in the relationship between the principal and agent there are justified reasons to believe that the agent, obliged by the contract to perform a service for the principal, will not always work in the best interest of the principal when their interests are in conflict. Knowing about the asymmetry of information and agency's problems, establishing efficient board of directors, suitable compensation systems, acting on the market of corporate control and through other mechanisms of corporate management, rational investors limit managers selfish, rational orientation (Todorović, 2011, p. 282). One of manifestations of this problem relates to manager's tendency to expand the limits of their company beyond optimal scope empire expansion syndrome. According to Jensen (1986), growth increases manager's power through the increase of resources that they control. Insisting on unjustified growth is a reason for investment in projects with negative Net Present Value, overpayment of other companies' shares and the like. These actions can be interpreted as a need for gaining greater control.

Despite the assumption that managers' opportunistic behavior might result in the occurrence of cost stickiness, for many years no empirical research, which would confirm it, has been done. Also, empire expansion syndrome is dominantly analyzed in literature through the prism of complex M\&A transactions (Motis 2007). However, Chen et al. (2012) found strong evidence that cost stickiness is positively associated with managers' empire building incentives due to the agency problem.

Contrary conclusions are reached if we consider managers' decisions that are made in order to accomplish defined profit goals. In order to realize personal gains such as a pay rise, bonus and other forms of compensation conditioned by achieving targeted financial performances, in case of a temporary drop in the activity volume managers may be motivated to adjust their resources to that lower level. Based on the concept of sticky costs, stimulus to meet earning targets will mostly result in the decrease of the level of cost stickiness (Kama \& Weiss, 2010). Empirical research confirmed these assumptions (Kama \& Weiss 2012). Dierynck et al. (2012) came to the conclusion that companies which tend to meet or beat zero earnings benchmark show greater readiness to reduce labor costs as the activity volume goes down, while labor costs in companies without this stimulus show stickiness in behavior.

However, it often happens that managers, in an attempt to maximize the value of the company, make decisions based on heuristics, which do not necessarily result in positive performance. Behavioral finance is based on the breakthrough of psychological principles into the finance theory. Tending to explain market anomalies as size effect, calendar effect, price bubble, market crash and the like (Todorović, 2011), supporters of this concept think that participants at the market are not usually rational, as it is envisaged by the conventional finance theory. Namely, it goes from the fact that individuals have limited abilities for solving complex problems, processing more data and instead of using sophisticated mathematical and statistical models, decisions are mostly based on intuition, former experience, emotions, as well as socially acceptable practices. Decisions on the level of resources are primarily based on expectations regarding the activity volume. In addition to the fact that these expectations are based on information on previous trends, the macroeconomic environment, they are also based on the personal judgment of managers about future trends. In general, people in a good mood are more optimistic in their choices and judgments than those in a bad mood. This also applies to managers. Among the heuristics recognized by behavioral finance theory, two stand out in the context of the effects they 
have on cost behavior: overconfidence and optimism. It is often considered that these two characteristics are so closely linked that they usually appear together. An individual, who shows overconfidence, is also overly optimistic, and vice-versa. However, there is a need to make a difference between overconfidence and optimism (Malmedier \& Tate 2005; Fabre \& Heude-Francois 2009).

Overconfidence is generally defined as having inaccurate, overly positive perceptions of one's abilities or knowledge, which is conceptualized in two ways in the psychology literature: better-than-average effect and miscalibration (Qin et al., 2015). The "better than average" effect is a type of social comparison in which individuals, comparing their characteristics (or behaviors) to a group (peers, co-workers) believe to be superior to an average representative of that group in various fields (Skala, 2008). According to Biais et al. (2004) miscalibration involves overestimating the precision of someone's information. Individuals who are calibrated well are able to see if they are making a mistake, and in this context, a surplus of confidence appears as a form of wrong calibration. "Optimism, on the other hand, can be defined as the tendency or inclination to perceive an event or action as more likely to result in a favorable outcome, irrespective of the objective probability of that outcome actually occurring" (Fabre \& Heude-Francois, 2009, p. 80). According to Li \& Zhang (2017, p. 307) "managerial optimism about future demand may prompt managers in firms facing a competitive environment to make investment expenditures in spite of a current sales downturn, while pessimism may cause managers to be unwilling to infuse resources, even to the point where they face strong competition from rivals". Therefore, confidence is primarily based on personal characteristics, skills, while optimism is a perception of external phenomena (Malmendier \& Tate, 2005, p. 2662).

Numerous authors researched behavioral factors as causes of stickiness in cost behavior. Chen et al. (2013), Qin et al. (2015) introduced managers' overconfidence into literature, as a behavioral factor of stickiness. Both studies confirmed that companies whose CEO shows a greater level of confidence experience higher level of cost stickiness. Salamah \& Abulezz (2017) showed that company's costs that are managed by managers who have the aversion to risk show the reversed stickiness (anti stickiness) in behavior. Namely, with a drop in the volume of sales, these managers adjust resources to the drop, not wanting to be exposed to the risk of bearing the costs of unused capacity. Li \& Zheng (2017, p. 311) found "evidence suggesting that cost stickiness arising from product market competition is increasing in managerial optimism, proxied by a prior period sales rise; whereas, managerial pessimism, proxied by a prior period sales fall, does not affect the relationship between competition and cost stickiness".

\section{DESCRIPTION OF DATA AND SAMPLE}

Presence of stickiness in cost behavior of companies that operate in Serbia will be tested on the sample of medium-sized and big companies belonging to manufacturing sector for the period 2007-2016. The size of a company is determined according to the level of sales revenue throughout the observed period, as a criterion. The research is based on the dataset based on data available in the official financial reports. As it is envisaged by appropriate rulebooks on the content and form of financial reports for companies, cooperatives and entrepreneurs that the income statement is to be made by using the method of total cost, we are not able to analyze the influence of the change of 
operating revenues on the change of the sales, general and administrative costs. Having in mind analogous studies (Calleya et al., 2006; Pervan \& Pervan, 2012; Kama \& Weiss, 2012; Dalla Via \& Perego, 2014; Pamplona et al., 2016), we decided to assess the influence of the change of sales revenue on the change of operating costs. In accordance with the requirements of econometric models in terms of data, we included into the sample companies having the data on operating revenues and operating costs for three years in a row, in a mentioned time interval, at which point the amount of operating revenues and operating costs is higher than 0. Afterwards we calculated the change of operating revenues and costs during two years in a row and performed data logarithmic which is in line with the conclusions of Banker \& Byzalov (2014). Finally, we excluded from the sample $1 \%$ of the highest and lowest variable values that are included in the model in order to neutralize the extreme values in the sample.

The final sample consists of 917 companies. It is an unbalanced panel, with the number of observations per company ranging from 1 to 8 , with an average of 7.125 observations, which makes that our sample has a total of 6,534 observations. Of the 917 companies in the sample, 197 are large and 720 are medium-sized.

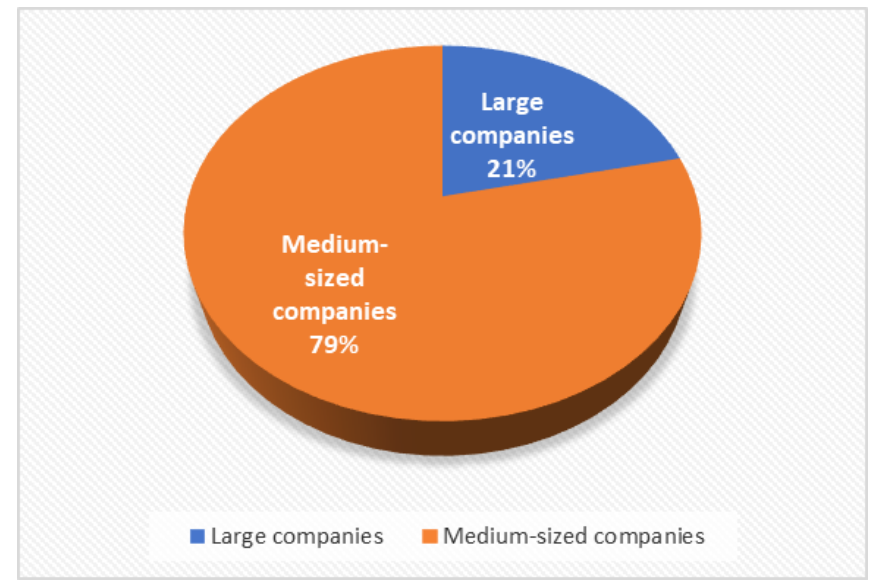

Fig. 3 Percentage of large and medium-sized companies in sample Source: Author's calculation

An overview of the movement of mean operating revenues and operating costs, with appropriate standard deviations, by year, for the group of large and the group of mediumsized companies from sample is presented in table 1.

In 2009 both groups of companies mark a fall in average operating revenues, but also in costs. After that came a period of continuous growth of these indicators, with the exception that in in 2014, compared to last year, there was a slight fall in average operating revenues and costs in the group of large companies. Growing operating revenues may be an indicator of the end of recession and overall improvement of business environment since 2010. 
Table 1 Mean values and standard deviations of operating revenues / operating costs by years, for the group of medium-sized and large companies in sample

\begin{tabular}{|c|c|c|c|c|c|c|c|c|}
\hline \multirow[t]{3}{*}{ Year } & \multicolumn{4}{|c|}{ Medium sized companies } & \multicolumn{4}{|c|}{ Large companies } \\
\hline & \multicolumn{2}{|c|}{$\begin{array}{c}\text { Operating revenues } \\
\text { (mill RSD) }\end{array}$} & \multicolumn{2}{|c|}{$\begin{array}{l}\text { Operating costs } \\
\text { (mill RSD) }\end{array}$} & \multicolumn{2}{|c|}{$\begin{array}{c}\text { Operating revenues } \\
\text { (mill RSD) }\end{array}$} & \multicolumn{2}{|c|}{$\begin{array}{l}\text { Operating costs } \\
\text { (mill RSD) }\end{array}$} \\
\hline & Mean & Std. Dev. & Mean & Std. Dev. & Mean & Std. Dev. & Mean & Std. Dev. \\
\hline 2007 & 577 & 638 & 541 & 600 & 6,286 & 21,094 & 6,055 & 20,460 \\
\hline 2008 & 665 & 729 & 623 & 680 & 7,051 & 24,736 & 6,807 & 24,256 \\
\hline 2009 & 636 & 649 & 590 & 584 & 5,810 & 12,771 & 5,519 & 12,474 \\
\hline 2010 & 758 & 798 & 702 & 723 & 7,196 & 16,656 & 6,665 & 14,863 \\
\hline 2011 & 911 & 1,011 & 848 & 932 & 7,776 & 18,243 & 7,292 & 16,166 \\
\hline 2012 & 1,031 & 1,102 & 964 & 1,019 & 8,564 & 20,029 & 7,879 & 16,575 \\
\hline 2013 & 1,044 & 1,144 & 987 & 1,068 & 9,693 & 24,666 & 9,032 & 21,667 \\
\hline 2014 & 1,102 & 997 & 1,047 & 993 & 9,578 & 23,468 & 8,946 & 20,703 \\
\hline 2015 & 1,209 & 1,008 & 1,148 & 996 & 10,239 & 21,464 & 9,542 & 19,281 \\
\hline 2016 & 1,323 & 1,087 & 1,235 & 1,043 & 11,197 & 23,530 & 10,316 & 21,064 \\
\hline
\end{tabular}

Source: Author's calculation

\section{SPECIFICATION OF PANEL MODEL AND INTERPRETATION OF RESULTS}

Methodology that Anderson et al. (2003) used was also used in later studies that dealt with this issue. Information about the sales, general and administrative costs are publicly available, while authors approximated the activity volume to the amount of operating revenues due to the data on physical sales volume being unavailable. Even though it is often stated as the limitation of the analysis, Banker and Byzalov (2014) emphasize that the use of operating revenues would be more purposeful even if this problem did not exist because the products, even of the companies doing business in the same branch, are somewhat differentiated, which makes physical units incomparable. Having in mind previous researches, as well as availability of data, we estimated the following model (1) in order to test cost stickiness:

$$
\log \frac{\mathrm{C}_{\mathrm{i}, \mathrm{t}}}{\mathrm{C}_{\mathrm{i}, \mathrm{t}-1}}=\beta_{0}+\beta_{1} \log \frac{\mathrm{R}_{\mathrm{i}, \mathrm{t}}}{\mathrm{R}_{\mathrm{i}, \mathrm{t}-1}}+\beta_{2}{ }^{*} \text { Dummy }_{\mathrm{i}, \mathrm{t}} * \log \frac{\mathrm{R}_{\mathrm{i}, \mathrm{t}}}{\mathrm{R}_{\mathrm{i}, \mathrm{t}-1}}+\varepsilon_{\mathrm{i}, \mathrm{t}}
$$

where:

$\mathrm{C}_{\mathrm{i}, \mathrm{t}}$ - amount of operating costs for company $\mathrm{i}$ in period $\mathrm{t}$,

$\mathrm{R}_{\mathrm{i}, \mathrm{t}}$ - amount of operating revenues ${ }^{3}$ (sales revenue is increased by revenues from activating own goods and increase of value of finished goods and work in process, and it is decreased by the drop in the value of finished goods and work in process) for company $\mathrm{i}$ in period $\mathrm{t}$,

Dummy variable $e_{i, t}-$ takes on value 1 in case of $R_{\mathrm{i}, \mathrm{t}}<\mathrm{R}_{\mathrm{i}, \mathrm{t}-1}$ or value 0 in case of $\mathrm{R}_{\mathrm{i}, \mathrm{t}}>\mathrm{R}_{\mathrm{i}, \mathrm{t}-\mathrm{1}}$.

\footnotetext{
${ }^{3}$ Having in mind the discrepancy between the schemes of profit and loss account which were used till 2014 and the schemes that were prescribed to be used starting from 2014, certain adjustments were made in order to achieve comparability. When we say discrepancies, we dominantly think of previously prescribed use of production orientated concept method of overall costs in the scheme of profit and loss account, and then the rulebook which envisages the use of market oriented concept method of overall costs was enforced. In order to carry out the analysis, data on operating revenues and expenses for the period 2014-2016 were corrected in a way that costs classified by type remain in the framework, and operating revenues includes, apart from revenues gained from sales, also revenues from activating own goods, as well as appropriate correction through finished goods and work in process.
} 
As dummy variable takes on value 0 upon the growth of revenues, coefficient $\beta_{1}$ shows proportional growth of operating costs with $1 \%$ growth of operating revenues, while in the case of fall in revenues dummy variable takes on value 1 , which means that the addition of coefficients $\beta_{1}+\beta 2$ shows proportional fall of operating costs upon $1 \%$ fall of operating revenues. Under the assumption that costs change, as it is envisaged by traditional theory, with a same amount in case of equivalent growth and fall of the activity volume, it is expected for a coefficient $\beta_{2}$ to take on value 0 .

In order to take into account the effect of time on cost stickiness, based on previous research, we applied extended model (2) to test if cost stickiness is reversed in subsequent periods:

where:

$$
\begin{aligned}
\log \frac{\mathrm{C}_{\mathrm{i}, \mathrm{t}}}{\mathrm{C}_{\mathrm{i}, \mathrm{t}-1}}=\beta_{0}+ & \beta_{1} \log \frac{\mathrm{R}_{\mathrm{i}, \mathrm{t}}}{\mathrm{R}_{\mathrm{i}, \mathrm{t}-1}}+\beta_{2}{ }^{*} \text { Dummy }_{\mathrm{i}, \mathrm{t}} * \log \frac{\mathrm{R}_{\mathrm{i}, \mathrm{t}}}{\mathrm{R}_{\mathrm{i}, \mathrm{t}-1}} \\
& +\beta_{3} \log \frac{\mathrm{R}_{\mathrm{i}, \mathrm{t}-1}}{\mathrm{R}_{\mathrm{i}, \mathrm{t}-2}}+\beta_{4}{ }^{*} \text { Dummy }_{\mathrm{i}, \mathrm{t}-1} * \log \frac{\mathrm{R}_{\mathrm{i}, \mathrm{t}-1}}{\mathrm{R}_{\mathrm{i}, \mathrm{t}-2}}+\varepsilon_{\mathrm{i}, \mathrm{t}}
\end{aligned}
$$

Dummy $y_{i, t-1}$ - takes on value 1 in case of $R_{i, t-1}<R_{i, t-2}$, or value 0 in case of $R_{i, t-1}>R_{i, t-2}$.

According to previous research, the $\beta_{3}$ coefficient, if positive, indicates a lagged adjustment to operating costs for changes in sales revenue. Further, the $\beta_{4}$ coefficient, if positive and lower than absolute value of $\beta_{2}$, indicates a partial reversal of the cost stickiness that follows a revenues decrease.

Choice of specification models was done in line with econometric procedure which entails the application of certain specification tests. The existence of individual effects was tested by the application of the F test for fixed specification and Breusch Pagan test for the random one. The existence of time effects is tested only by the application of the $\mathrm{F}$ test, having in mind that it is about a short-term time horizon and a large number of observation units.

Table 2 Specification tests

\begin{tabular}{lcccc}
\hline Test & \multicolumn{2}{c}{ Realized value of test statistics } & \multicolumn{2}{c}{ p-value } \\
\cline { 2 - 5 } & Model 1 & Model 2 & Model 1 & Model 2 \\
\hline F-test (fixed individual) & 0.74 & 0.70 & 1.0000 & 1.0000 \\
Breusch-Pagan (random individual) & 0.00 & 0.00 & 1.0000 & 1.0000 \\
F-test (time effects) & 13.15 & 13.03 & 0.0000 & 0.0000 \\
\hline
\end{tabular}

Source: Author's calculation

Conducted tests point to the fact that individual effects are not statistically important. On the other hand, based on realized value of F statistics, it is concluded that there are significant time effects. We can assume that such a result is the result of a dynamic macroeconomic environment conditioned by the crisis effect of 2008 and 2009. The inclusion of time effects in a regression models was done by introducing dummy variables in the model. In order to neutralize potential autocorrelation and heteroscedasticity problems, specifications with cluster-robust standard errors are used. Estimated coefficients are presented in table 3 for both models. 
Table 3 Estimated coefficients

\begin{tabular}{lcc}
\hline & Model 1 & Model 2 \\
\hline$\beta_{1}$ & $0.8469394^{*}$ & $0.8485476^{*}$ \\
& $(0.0129047)$ & $(0.0143084)$ \\
\hline$\beta_{2}$ & $-0.1286175^{*}$ & $-0.140712^{*}$ \\
& $(0.0244261)$ & $(0.026359)$ \\
\hline$\beta_{3}$ & & $0.0107644^{*}$ \\
& & $(0.0048706)$ \\
\hline$\beta_{4}$ & & $0.0705936^{*}$ \\
& & $(0.0211013)$ \\
\hline
\end{tabular}

Notes: Standard errors are given in parentheses; ${ }^{*}$-significance level of $5 \%$. Source: Author's calculation using Stata software

Estimated regression models are both significant as a whole, with the calculated $\mathrm{F}$ statistics of 865.21 and 788.04 respectively and appropriate p-values of 0.0000 .

Estimated value of the coefficients $\beta_{1}$ in model 1 points to the fact that operating costs increase on average $0.847 \%$ per $1 \%$ growth of operating revenues, while, on average, they decrease by $0.718 \%$ upon the fall of operating revenues by $1 \%$, which points to the existence of stickiness in operating costs of observed companies. Estimated values of coefficients are statistically significant, at the value level of 5\%. Results are comparable with the results gained from the research of Calleya et al. (2006), where the authors established that operational costs increase by $0.97 \%$ on average with $1 \%$ growth of revenues, while on the contrary they decrease by $0.91 \%$. Dalla Via and Perego (2014) showed that operational costs increase by $0.94 \%$ on average with $1 \%$ growth of revenues in manufacturing industry, but they found coefficient $\beta_{2}$ to be positive. Bugeja et al. (2015) found that costs of Australian listed firms increase by $0.885 \%$ with $1 \%$ increase in operating revenues, but decrease by only $0.797 \%$ for $1 \%$ decrease in operating revenues.

We can find few potential causes of identified presence of cost stickiness. Companies from our sample belong to manufacturing sector which is characterized by greater level of fixed assets: machinery, plants and equipment than trading and service sectors. These committed resources cause high adjustment costs, which promotes the emergence of cost stickiness. This is in line with conclusions of Weidenmier and Subramaniam (2003). Having in mind that managers rely on information about past operating revenues in forming expectations about future demand, other potential cause of observed cost stickiness may be managers' optimism. Since there is a continuous growth of business activity, measured by the amount of operating revenues in the observed period, managers will be hesitant to reduce unused resources in the case of a slight decrease of demand in order to avoid adjustment costs. We can assume that the trend of growth is caused by the exit from recession and overall improvement of business environment since 2010. Besides, as it is emphasized in Pervan \& Pervan (2012), the only similar research done in the field of sticky costs in the region, managers of state owned companies are surely less prone to dismiss workers in the conditions of fall in business activities due to the implementation of social and employment policies, which can be reflected in these results. However, the confirmation of these assumptions requires similar researches to be done at the level of labor costs, in companies with a different ownership structure. Another potential cause of identified cost stickiness may be managerial empire-building incentives. According to 
Chen et al. (2012) cost stickiness is more pronounced under weak corporate governance. This is, mainly, a problem of state owned companies.

Estimated coefficients $\beta_{1}$ and $\beta_{2}$ in model 2 are similar to their counterparts in model 1 , which confirms cost stickiness. The positive and significant estimated coefficient $\beta_{3}$ indicates a lagged adjustment to operating costs for changes in operating revenues. Additionally, the estimated coefficient $\beta_{4}$ is, also, positive and significant, and its value is less than absolute value of estimated coefficient $\beta_{2}(0.0705936<|-0.140712|)$ implying a partial reversal of stickiness in the period after a revenue decrease. We can interpret this as manager's caution in deciding to reduce resources, which takes some time to obtain information about the persistence of changing demand. The other explanation could be that contractual arrangements related to committed resources take time to be undone. Besides, cost stickiness observed in one period is partly reverted in subsequent period, after a revenue decrease. "During longer time intervals, the managerial assessment about the permanence of a change in revenues becomes more precise and then adjustment costs become lower relative to the cost of keeping unused resources" (De Medeiros \& Costa, 2004). This shows us that cost stickiness is less pronounced when observed in a longer time period.

\section{CONCLUSION}

Determining the pattern of cost behavior is not at all simple. Traditional cost theory classifies costs into two groups, depending on how they react in total to a change in the activity volume: fixed and variable costs. However, the costs show different features depending on the time horizon that is observed. In addition, the complexity is especially pronounced when we keep in mind that costs do not have a strictly defined character, but that their behavior is determined by numerous factors. Determining the way in which costs move with the change in the activity volume is essential for the needs of planning, cost control, as well as making individual business and financial decisions.

The theory of sticky costs indicates that the variable and fixed are the two extreme cost categories determined by low and high adjustment costs, respectively. Anderson et al. (2003) consider deliberate decision making on resource adjustment as the primary cause of stickiness in the cost behavior. Taking into account the direction of activity volume change, the authors concluded that managers make different decisions on resource adjustment in case of increase or decrease in activity volume.

Despite popularity and growing interest in this subject in the expert literature, some authors were critical of the theory of sticky cost behavior (e.g. Anderson \& Lanen, 2007). In spite of this, it is certain that the results of the studies based on sticky cost theory provided researchers with enthusiasm regarding the analysis of cost behavior, placing it into new context which is compatible with contemporary ideas of the theory of finance, presented by behavioral finance. Framework of sticky costs presents a different way of thinking about the cost behavior in relation to the activity volume, not necessarily opposed to the conventional theory. A better understanding of cost behavior results in more precise and better cost planning. "At a shorter time horizon, cost stickiness potentially affects those corporate decisions which use some variant on a theme of average/standard costs and which typically do not acknowledge that costs, for managerial considerations, do not behave as anticipated" (Calleya et al., 2006, 140). The settings of this theory are also important for the 
purpose of predicting financial performance, both for financial analysts and existing and potential investors. Ignoring this phenomenon in cost behavior could result in underestimation of budgeted costs in case of less desirable outcomes (decline in sales volume), and thus overestimation of profitability. Previous researches testify to minimal awareness of asymmetric cost behavior (e.g. Novák et al., 2018).

Starting from the methodology introduced by Anderson et al. (2003), we have shown that the costs of medium and large manufacturing companies that operate in Serbia show stickiness. Similar research for our country has not been conducted, which makes this one a basis for further studies. In addition, it would be possible to include certain elements of operating costs in the research - i.e. certain categories of costs, where, in the context of adjustment costs, the focus would be on salary costs. Future research should focus on determinants of cost stickiness of domestic companies, bearing in mind the complex macroeconomic environment to which companies are exposed in the domestic market, which exceeds the empirical part of this paper. This type of research would enable a better understanding of the business decision-making process, but would also make some progress in the development of cost accounting in our country

This research has certain limitations. First of all, we used the amount of sales revenue as a proxy variable for the scope of activities due to the lack of a more adequate publicly available variable. In addition, we must keep in mind that changes in costs and revenues, as proxy variables for activity volume, are conditioned not only by higher sales volumes, but also by changes in sales prices.

\section{REFERENCES}

Anderson, M. C., Banker, R. D., \& Janakiraman, S. N. (2003). Are selling, general, and administrative costs "sticky". Journal of Accounting Research, 41(1), 47-63.

Anderson, S., \& Lanen, W. (2007). Understanding cost management: What can we learn from the evidence on 'sticky costs'? (Working Paper), Melbourne: University of Melbourne.

Balakrishnan, R., \& Gruca, T. (2008). Cost Stickiness and Core Competency: A Note. Contemporary Accounting Research, 25(4), 993-1006.

Banker, R., \& Byzalov, D. (2014). Asymmetric Cost Behavior. Journal of Management Accounting Reserch, 26(2), 43-79.

Banker, R., Byzalov, D., \& Chen, L. (2013). Employment Protection Legislation, Adjustment Costs and Cross-Country Differences in Cost Behavior. Journal of Accounting \& Economics, 55,111-127. http://dx.doi.org/10.1016/ j.jacceco.2012.08.003

Banker, R., Byzalov, D., Fang, S., \& Liang, Y. (2018). Cost Management Research. Journal of Management Accounting Research, 30(3), 187-209.

Banker, R., Ciftci, M., \& Mashruwala, R. (2008). Managerial Optimism, Prior Period Sales Changes, and Sticky Cost Behavior. Retrieved from: https://dx.doi.org/10.2139/ssrn.1599284

Biais, B., Hilton, D., Mazurier, K., \& Pouget, S. (2008). Judgemental Overconfidence, Self-Monitoring, and Trading Performance in an Experimental Financial Market. Review of Economic Studies, 72(2), 287-312.

Bugeja, M., Lu, M., \& Shan, Y. (2015). Cost stickiness in Australia: Characteristics and determinants. Australian Accounting Review, 25(3), 248-261.

Calleya, K., Steliaros, M., \& Thomas, D. C. (2006). A note on cost stickiness: Some international comparisons. Management Accounting Research, 17(2), 127-140.

Chen, C. X., Gores, T., \& Nasev, J. (2013). Managerial overconfidence and cost stickiness (Working paper), University of Illinois at Urbana-Champaign and University of Cologne. https://doi.org/10.2139/ssrn.2208622

Chen, C. X., Lu, H., \& Sougiannis, T. (2012). The Agency Problem, Corporate Governance, and the Asymmetrical Behavior of Selling, General, and Administrative Costs. Contemporary Accounting Research, 29(1), $252-282$.

Cooper, R., \& Kaplan, R. (1992). Activity-based Systems: Measuring the Costs of Resource Usage. Accounting Horizons, September 1992, 1-13. 
Dalla Via, N., \& Perego, P. (2014). Sticky cost behaviour: evidence from small and medium sized companies. Accounting and Finance, 54(3), 753-778.

De Medeiros, O. R., \& Costa, P. D. S. (2004). Cost stickiness in Brazilian firms. Available at SSRN 632365: https://ssrn.com/abstract=632365.

Dierynck, B., Landsman, W. R., \& Renders, A. (2012). Do managerial incentives drive cost behavior? Evidence about the roles of the zero earnings benchmark for labor cost behavior in Belgian private firms. The Accounting Review, 87(4), 1219-1246. https://doi.org/10.2308/accr-50153

Fabre, B., \& Heude-Francois, A. (2009). Optimism and overconfidence investors' biases: a methodological note. Finance, 30(1), 79-119.

Guenther, T. W., Riehl, A., \& Rößler, R. (2014). Cost stickiness: state of the art of research and implications. Journal of Management Control, 24(4), 301-318.

Hamermesh, D. S., \& Pfann, G. A. (1996). Adjustment costs in factor demand. Journal of Economic literature, 34(3), 1264-1292.

Jensen, M. C. (1986). Agency costs of free cash flow, corporate finance, and takeovers. The American economic review, 76(2), 323-329.

Kama, I., \& Weiss, D. (2012). Do Ernings Targets and Managerial Incentives Affect Sticky Costs. Journal of Accounting Research, 51(1), 201-224. https://doi.org/10.1111/j.1475-679X.2012.00471.x

Kama, I., \& Weiss, D. (2010). Do managers' deliberate decisions induce sticky costs?. Tel Aviv University, Faculty of Management, The Leon Recanati Graduate School of Business Administration.

Li, W. L., \& Zheng, K. (2017). Product market competition and cost stickiness. Review of Quantitative Finance and Accounting, 49(2), 283-313.

Lucas, R. (1967). Adjustment Costs and the Theory of Supply. The Journal of Political Economy, 75(4), 321-334.

Maher, M., Stickey, C., \& Weil, R. (2008). Managerial Accounting: An Introduction to Concepts, Methods and Uses. Thomson: South-Western.

Malinić, D., Milićević, V., \& Stevanović, N. (2018). Upravljačko računovodstvo [Management Accounting]. Ekonomski fakultet Beograd.

Malmendier, U., \& Tate, G. (2005). CEO overconfidence and Corporate Investment. The Journal of Finance, $60(6), 2661-2700$.

Motis, J. (2007). Mergers and acquisitions motives. Toulouse School of Economics EHESS (GREMAQ) and University of Crete. Retrieved from https://economics.soc.uoc.gr/wpa/docs/paper2mottis.pdf

Noreen, E., \& Soderstrom, N. (1997). The Accuracy of Proportional Cost Models: Evidence from Hospital Service Departments. Review of Accounting Studies, 2(1), 89-114.

Novák, P., Dvorský, J., Popesko, B., \& Strouhal, J. (2017). Analysis of overhead cost behavior: case study on decision-making approach. Journal of International Studies, 10(1),74-91. https://doi.org/10.14254/20718330.2017/10-1/5

Novák, P., Hrušecká, D., \& Macurová, L. (2018). Perception of cost behaviour in industrial firms with emphasis on logistics and its costs. FME Transactions, 46(4), 658-667. https://doi.org/10.5937/fmet1804658N

Pamplona, E., Fiirst, C., de Jesus Silva, T. B., \& da Silva Zonatto, V. C. (2016). Sticky costs in cost behavior of the largest companies in Brazil, Chile and Mexico. Contaduría y Administración, 61(4), 682-704.

Pervan, M., \& Pervan, I. (2012). Sticky costs: evidence from Croatian food and beverage industry. International Journal of Mathematical Models and Methods in Applied Sciences, 8(6), 963-970.

Qin, B., Mohan Warsha, A., \& Kuang, F. Y. (2015). CEO Overconfidence and Cost Stickiness. Management Control \& Accounting, 2015(2), 34-38.

Regulation on the classification of activities, https://www.paragraf.rs/propisi/uredba_o klasifikaciji_delatnosti.html

Salamah, M. A., \& Abulezz, E. M. (2017). Cost Stickiness: Does Manager's Preference Toward Risk Matter? An Empirical Study. SSRN Electronic Journal. https://dx.doi.org/10.2139/ssrn.3492541

Serbian Business Registers Agency. http://www.apr.gov.rs

Skala, D. (2008). Overconfidence in Psychology and Finance - an Interdisciplinary Literature Review. Bank $i$ Kredyt, 4, 33-50.

Todorović, M. (2011). Psihologija i finansijski menadžment: bihevioralne korporativne finansije [Psychology and Financial Management: Behavioral Corporate Finance]. Ekonomika preduzé́a, 275-287.

Weidenmier, M., \& Subramaniam, C. (2003). Additional Evidence on the Sticky Behavior of Costs. Working Paper, Texas Christian University. 


\section{DA LI SU TROŠKOVI ASIMETRIČNI - PRIMER SRBIJE}

Rad je fokusiran na teoriju asimetričnih troškova, iznedrenu istraživanjima koja su ukazala na činjenicu da troškovi ne reaguju simetrično u slučaju ekvivalentnog povećanja i smanjenja obima aktivnosti, kao što to podrazumeva tradicionalna teorija troškova. Poslovne odluke donete u cilju povećanja vrednosti kompanije, kao i oportunističke odluke, usmerene na ostvarenje ličnih ciljeva menadžera, ističu se kao jedan od osnovnih uzroka asimetrije troškova. Da bismo ispitali postojanje asimetrije u kretanju troškova kompanija koje posluju u Srbiji, sproveli smo istraživanje na uzorku od 917 srednjih $i$ velikih preduzeća iz proizvodnog sektora za period 2007 - 2016. Analiza panel podataka ukazala je na prisustvo asimetrije u ponašanju ukupnih troškova, odnosno, pokazala je da ukupni troškovi rastu za 0,847\% u slučaju 1\%-og rasta poslovnih prihoda, a padaju za 0,718\% usled 1\%-og pada poslovnih prihoda. Utvrdili smo i da se troškovi uz kašnjenje prilagođavaju poslovnim prihodima, kao i da postoji parcijalna reverzibilnost asimetrije troškova $u$ periodu koji sledi period pada poslovnih prihoda.

Ključne reči: kretanje troškova, asimetrija troškova, troškovi prilagođavanja, bihevioralne finansije, agencijska teorija 